\title{
7 The arena of the colony: Phoolan Devi and postcolonial critique
}

\author{
Sandra Ponzanesi
}

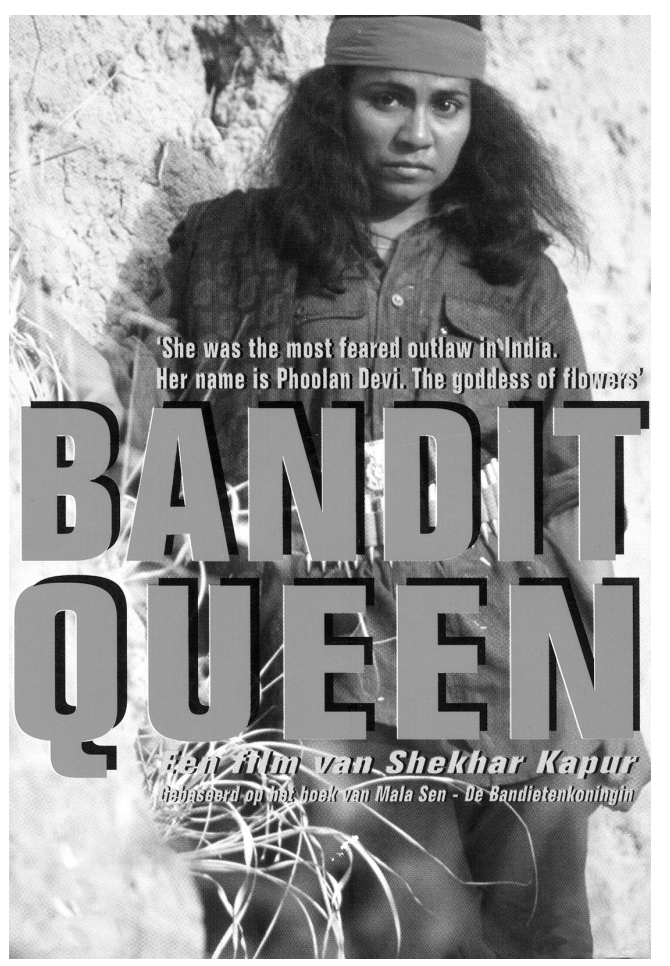

Figure 7.1 Poster of the film Bandit Queen, about the life of Phoolan Devi. (C) Anne-Marie van Warmerdam

In February 1994, a woman of legendary status, Phoolan Devi, was released from prison in the full glare of the media of the Indian nation. ${ }^{1}$ Better known as the Bandit Queen, the Avenging Angel or the Rebel of the Ravines, Devi made a remarkable transformation from lower-caste fisherman's daughter (a mallah) to a member of the Indian Parliament in 1996.

With a red bandana on her head and a rifle in her hand, Phoolan Devi had become the popular embodiment of cruel and bloodthirsty goddesses such as Kali or Durga. Kali is the goddess of destruction, and the patron of dacoits (bandits). She reputedly slaughtered her enemies with her thousand arms and with a smile on her face. Durga is the goddess of war and notorious for her slaughter of demons. Phoolan Devi's larger-than-life image is that of a victim of caste oppression and gender exploitation, who fought back first by 
resorting to acts of revenge and later by moving on to the political plane. There, she metamorphosed into a phenomenal leader who waged a persistent struggle on behalf of the weak and downtrodden.

Married off at 11 years of age to a man three times her age, Devi ran away after being abused and was consequently abandoned by her family. By the time she was 20 years old she had been subjected to several sexual assaults, both by higher caste men (thakurs or landowners) and by police officers during her unexplained arrests. She was then abducted by a gang of dacoits and had no way to return to normal society. She subsequently became the lover of the gang leader, Vikram Mallah, who like herself was from a lower caste, until he was killed by a higher caste rival. Devi was kidnapped and brought to the village of Behmai, where she became the victim of a collective rape by higher caste men.

This was a turning point in Phoolan Devi's life, as she then decided to take revenge by forming her own gang of dacoits. She was feared by other gangs, thwarted police attempts to catch her, and raided the ravines of Uttar Pradesh for many years, robbing from the rich and redistributing her loot to the poor. These acts turned her into a legendary champion of the oppressed; a female Robin Hood in modern India with its feudal system of caste oppression and female exploitation. In 1981, Phoolan Devi was charged with the murder of 22 thakurs in Behmai. She denied any involvement but decided to surrender to the police in the central state of Madhya Pradesh in 1983, after carefully negotiating the terms of her surrender with the then primary minister of India, Indira Gandhi.

When she was released on parole in 1994 (her involvement in the massacre of Behmai still to be determined), she joined the regional Samajwadi Party (Socialist Party), which represents the lower castes that account for about 85 per cent of those eligible to vote in India. Devi, a feisty, blunt speaker who drew large crowds, became a member of the Lower House of Parliament in 1996, was defeated in the 1998 election, and made a comeback in 1999. A few months before the 2001 election, Phoolan Devi was brutally murdered with six bullets outside her official residence in Delhi in a high-security neighbourhood, by two masked men who managed to escape. ${ }^{2}$

The news shocked the nation and the world beyond as the Bandit Queen's reputation knew no boundaries. Devi's image combining crime and fame outside India was due in particular to the controversy surrounding The Bandit Queen, a film based on Phoolan Devi's life that was made by Shekhar Kapur and financed by Channel 4 . The film was presented at Cannes in May 1994. Several critics considered the production to be among India's 20 best films of recent years.

The film was meant to overcome the boundaries between East and West and combines the style of European arthouse films with Bollywood escapist entertainment. This hybrid form allows for a revolutionary foregrounding of two aspects that are silenced by Indian politicians: both the oppression of women and the Indian caste system are denounced. In order to achieve this effect, the filmmaker focused on two aspects of Devi's life: the rape by several higher caste men from the village of Behmai and the revenge she takes on her rapists by killing them a number of years later. The film originally opened with the claim that 'this is a true story' and was based on the biography published by Mala Sen, India's Bandit Queen: The True Story of Phoolan Devi (1991). As Leela Fernandes writes, 'the film sparked a contentious and distinctive debate on the politics of authenticity, agency, authority, and responsibility in the representation of the "real" life experience and struggle of an individual' (Fernandes 1999: 128).

Devi's involvement in the Behmai massacre was still under legal scrutiny when the film premiered in Cannes and the film's claim to truth could have sent her straight back 
to jail. Phoolan Devi denied both aspects, the rape and the revenge, and threatened to burn herself alive outside the Indian Board of Film Censors if the film was not banned. While Kapur claims to reflect the reality of rural India, where the rape of lower caste women is not even considered an issue, Devi resisted her objectification in the film as an abused and raped rural woman. For a more critical understanding of how films operate transnationally, it is important to take into account how cinematic language and postcolonial interventions can be combined (Ponzanesi and Waller 2012), something which was not fully realized by Kapur's adaptation of Devi's life. In acknowledging the oppression of women in India, the film has a consciousness raising effect; but it also glorifies oppression by playing with excessively sensationalistic images of violence against the Indian downtrodden woman. Eventually the ban was lifted and the film became a moderate box-office success in India, while internationally it received critical recognition and many awards.

The fact-versus-fiction issue was brought again to the attention of the Indian public in a double essay called 'The Great Indian Rape Trick, Part I and II', which was written by one of India's most prominent writers, Arundhati Roy, in 1994. Roy attacked Kapur's claim that the film was a true story (later, the claim was removed from the opening titles). She wrote in defence of former dacoit Phoolan Devi, whom she felt had been ruthlessly exploited by Shekhar Kapur's film. Arundhati Roy dismantles Kapur's claim to truth bit by bit by making a close comparison between the biography written by Mala Sen and the characters, plot and motives chosen in the film. The biography was based on interviews, newspaper reports and information dictated by Phoolan Devi in prison.

Roy's major accusation is that Phoolan Devi, the woman, has ceased to be important to the filmmaker. As she is suffering from a case of 'Legenditis', she has become only a caricature of herself in the film. Kapur visualizes rape and oppression in order to say something about the life of Indian women, but also for commercial reasons. This exploitation of Devi's legacy is, according to Roy, more deadly and disempowering than any assaults endured by Devi during her life.

What can we conclude from this debate? Who was the Bandit Queen? Was she a fraud? A femme fatale? A woman warrior? A politician on the make? The debate unravels the part played by stories and the media in the construction of female identity. Devi can claim to be the only one to have the right to her own true story. However, because she had become a legend constructed through many layers of media reports and several cinematographic and printed biographies, ascertaining who is entitled to tell whose story and who is entitled to the 'truest' version becomes rather complex (see also Devi and Cuny 1996 and Devi, Cuny and Rambali 2006). This case is exemplary in illustrating a number of feminist topics that seem to plague the relationship between, on the one hand, western forms of representation of the Other, and on the other hand, the postcolonial subject's attempts to claim a voice of his/her own and determine moments of agency on his/her own terms. How can we develop a notion of female emancipation beyond the western ideological framework? And how can we develop a form of solidarity which takes into account diversity without falling into cultural relativism or political correctness?

These are central questions for postcolonial critique. Issues such as those surrounding Phoolan Devi cannot be studied properly without taking into account the insights that have emerged from this interdisciplinary field of studies. In order to locate the debate on the Bandit Queen in the context of feminist postcolonial studies, a brief survey is required of the most pertinent aspects that have emerged from this discipline. 


\section{The postcolonial debate}

Postcolonialism is an interdisciplinary field of studies that is not characterized by a cohesive set of theories and methods. However, a definition is possible. The common denominator of postcolonial studies is that it offers critical tools for exposing, studying and interrogating the ongoing legacies and discursive operations of empire. Postcolonialism considers the perspectives that were silenced by colonization. Take, for example, the colonial idea that the West brought culture to previously uncivilized societies. Postcolonialism makes a plea for the interrogation of the concepts of culture and identity. In the colonial discourse these concepts function mainly as a western tool for dominating, exploiting and silencing other histories and traditions.

In historical terms, postcolonialism refers to the period of independence after colonization. The dates of this period are different for the individual nations involved. India, for example, became independent from the British Empire in 1947, Algeria from France in 1962, and Mozambique from Portugal only in 1975. However, more than a chronological phenomenon, postcolonialism should be conceived of as an intellectual movement that re-interprets the relationship between the metropolitan centre and the colonial outposts by proposing a reversal of roles. The 'postcolonial' works to shift the object that is scrutinized and spoken for towards a subjective position in which the postcolonial subject actively represents him/herself from his/her own perspectives and speaks back.

Whether this postcolonial consciousness emerged before or after independence is still subject to debate, along with the question as to whether this colonial hangover will ever belong to the past. We can affirm that postcolonialism comes into being when there is an awareness of oppression that is coupled with the need to articulate resistance to colonial hegemony - a dynamic of power struggle that is still present in today's society.

However, there is agreement on the text that inaugurated postcolonial critical discourse and caused it to blossom: Orientalism (1978) by Edward Said. A literary scholar of Palestinian origin, Said grew up in Cairo where he attended the American school. He continued his education in the United States, where he lived until his premature death in 2003. In Orientalism, Said developed a sophisticated discursive approach that linked Foucault's notion of knowledge and power to Gramsci's concept of hegemony by combining the analysis of political colonial dynamics with representational issues.

He argued that the most damaging and lasting effect of colonization was not caused by western military domination or by the violence perpetrated in the colonies, but rather lay in the construction of western scholarship on the Orient. Such scholarship constituted in truth a 'Western style for dominating, restructuring, and having authority over the Other' (Said 1978: 3). Said refers here to the ideological use of colonial doctrines such as philology, literature, painting, medicine, ethnography, evolutionary theory (such as social Darwinism), racial theories and cartography. Together they form the supposedly scientific practice of Orientalism, which constructed the 'Orient' as the exotic, irrational and feminized Other that was fixed in time. The Orient was, therefore, an invention, necessary for defining the West as superior or for projecting Europe's own fears and desires onto the Other. According to Said, the 'Other' was thus deprived of identity and subjectivity and was submitted to a detailed and differentiated map of representation, according to which no space is left for his/her own voice and desire. It was in order to install and perpetuate hegemony that certain discourses on otherness as racial inferiority had been invented, enforced and propagated. 
The success of postcolonial critique consisted both in the reappraisal of Said's Orientalism and in the criticism of this seminal text, which was found to contain a number of deep-rooted contradictions and several shortcomings. Homi Bhabha (1994), for example, problematized Said's rigid dichotomy, which fixed the Oriental Other as a passive, victimized subject without envisioning any possibility of resistance. Whereas Said focused almost entirely on the colonizer, Bhabha highlights the complex psycho-political dynamics between the colonizer and the colonized. He focuses on the reciprocity of negotiations across the colonial divide and beyond the system of binary oppositions that underlie Said's argument.

For Bhabha, the colonial discourse is never quite as authoritative and unified as it claims to be. Rather, it is in the gaps, contradictions and slippages of colonial rule that the subjectivity and agency of the colonized subject can be detected. Bhabha integrates postcolonial experience with poststructuralist thought, which is based on the work of Lacan, Derrida and Foucault and which postulates the splitting of the subject and the destabilization of margins and centres. Thus, he is able to articulate the possibility of resistance for postcolonial subjects, minorities, migrants and subalterns.

Both Said and Bhabha are blind to the gender implications of colonial discourse. Said's book, Orientalism, failed to show the interaction between gender and empire in much detail. In reality, gender plays a crucial part in Said's book. The relation between the Occident and the Orient is defined in terms of power and domination, and Orientalism is posited as an exclusively male phenomenon, with the Oriental woman a projection of European male fantasy. Nonetheless, Said refrained from exploring the relevant female perspective. Anne McClintock criticizes Bhabha for the same reason in her article 'The Return of the Female Fetishism' (1994: 2). She argues that Bhabha acknowledges female agency only when it is represented by men. The postcolonial debate has therefore been accused, especially in its initial forms, of gender blindness and of upholding masculinist notions of nationalism and resistance.

Gender relations have instead played a crucial part in the operation of colonization and in the rise of nationalist movements. McClintock (1997) extensively discusses the image of woman in the colonial arena as a site of controversy and an object of control, rather than a locatable agency within the conflicting policy of empire. She discusses 'Algeria Unveiled', an influential essay from 1965, in which Franz Fanon argued that the liberation of women was part and parcel of the nationalist project of Algerian liberation (Fanon 1965). Fanon illustrates in an original way how during the Algerian War the veil played a pivotal role in power relations between the Algerians and the French. The veil became a symbol of resistance during the revolution. As Fanon explained, this was due to the colonialist fantasy of unveiling Algeria's women, which meant possessing them and thus, by way of metonymy, possessing Algeria as a country. Fanon was among the first to recognize the 'historical meaning of the veil'. He analyzed how Algerian women veiled, unveiled and revealed themselves while participating in terrorist activities, in order to reverse the stereotypical colonial expectations of the French army while simultaneously trespassing the limits of patriarchal traditional roles. A significant and beautiful illustration of this phenomenon is formed by Gillo Pontecorvo's film The Battle of Algiers (1966). The film follows the tactics and strategies of the FLN (Front de Libération Nationale) - the armed movement that organized the masses to rebel against French colonization - and visualizes the strategic role played by women as illustrated by Fanon. Pontecorvo shows how women carried weapons and bombs under their veils, deceiving the French military at checkpoints. Once this device was discovered, all women were suddenly subjected to severe scrutiny. Militant 
Algerian women subsequently mimicked the colonial masquerade. They dressed up in western clothes, cut their hair, and 'unveiled' their faces. Thus, they played with French expectations and stereotypes about the role of women in Islamic society.

However, it is debatable whether women really gained a subject position via this participation in terrorist activities, or whether the strategic unveiling is simply a symptom of their 'designated agency'. This term was coined by McClintock in order to refer to an agency by invitation only: 'female militancy in short is simply a passive offspring of male agency and the structural necessity of the war' (McClintock 1997: 98). While Fanon deals with the nuances in the Algerian struggle for independence and represents women as taking part in this common effort, he does not fully consider how women's distinct agency should be implicated in the formation of the nation. According to McClintock, Fanon does not go beyond describing women as a kind of arsenal for the male position in combat. In the end, he denies the historical dynamism of the veil, which counters his original position in which he had refused to invest the veil with an essentialist meaning (the sign of women's servitude).

Other feminist critics, such as Assia Djebar (1992), Winifred Woodhull (1993 and 2003), and Meyda Yeğenoğlu (2003), also engage with Fanon's article 'Algeria Unveiled'. They read it against the grain and articulate possibilities for female agency in the gaps of dominant historiography. According to Yeğenoğlu, for example, the veil allows women to see without being seen. It creates a position of empowerment and frustrates western men's desire to know what is behind the veil. Thus, the veil thwarts the scopophilic pleasure of the western male gaze and becomes a site of resistance.

\section{Feminist postcolonial theories: 'Can the Subaltern Speak?'}

Feminist postcolonial interventions are challenging both the configuration of western feminism and of postcolonial theories vis-à-vis gender discourses. This means that crucial postcolonial questions are tackled from a feminist perspective, such as whether the female subaltern has a voice outside western categories of thought. To answer this question, feminist postcolonial theory proposes a radical rethinking of gender and agency, not just as context-bound concepts but also as categories that need constant interrogation in order to have operational value.

Gayatri Spivak, the third important postcolonial critic in the 'holy trinity' (Said, Bhabha and Spivak), is the first to have inflected the analyses of colonial discourse with a feminist agenda. Spivak addresses the epistemological problem of representability for people of the Third World and in particular for subaltern women. Her seminal article 'Can the Subaltern Speak?' (1985) is informed by feminism, psychoanalysis, Marxism and deconstructionism. ${ }^{3}$ Here, she argues that the category of 'Third World Woman' is an effect of discourse, rather than an existent, identifiable reality. In order to support her argument, Spivak applies her analysis to the Indian case of sati, the religious practice of the widow's immolation on her deceased husband's funeral pyre. Spivak dives into the colonial archives and wonders whether it is possible, on the basis of the available sources - the reports of the British colonial administration, which wanted to ban sati, and the Sanskrit texts, which considered it to be part of the Hindu religious tradition - to retrieve the voice and agency of those Hindu women who indeed opted for self-immolation.

Spivak concludes that the 'subaltern cannot speak' (Spivak 1988: 308). The voice and agency of subaltern women are doubly embedded, in Hindu patriarchal codes of religious

The arena of the colony $\bullet 99$ 
and moral conduct and in the British colonial representation of subaltern women as victims of a barbaric Hindu culture. These voices are impossible to recover. Or rather, the voice and subjectivity of the female subaltern are erased as she becomes the object of dispute between tradition and emancipation. She can only be represented and spoken for by others, in a distorted or 'interested' fashion. As Spivak succinctly and memorably put it: 'White man [wanted to save] brown women from brown men' (ibid.: 297).

Taking inspiration from Marx's Eighteen Brumaire of Louis Bonaparte (1851-1852), Spivak analyzes the problem of 'representation' of the oppressed as the subject of knowledge, who 'cannot represent themselves: [but] must be represented' (ibid.: 276). She refers to the double meaning of representation as expressed in German, where it signifies both vertreten, or representation as 'speaking for' (as in politics), and darstellen, or re-presentation as portrayal (as in art or philosophy) (ibid.). The two senses of representation - referring on the one hand to state formation and the law, and on the other to the theory of the subject - are related, according to Spivak, but also irreducibly discontinuous. They should never be conflated. The two related meanings point to the relationship between nation-state alliances (domination in geopolitics) and global capitalism (exploitation in economics) (ibid.: 70). Critical theorists, Spivak continues, cannot afford to overlook these two senses in the category of representation:

They must note how the staging of the world in representation - its scene of writing, its Darstellung - dissimulates the choice of and need for 'heroes', paternal proxies, agents of power - Vertretung.

(ibid.: 279)

Unless western intellectuals, including western feminists, start taking into account the aesthetic dimension of political representation, the voice of subaltern women will continue to be silenced. As was observed by Ania Loomba, Spivak signals the necessity of adapting the Gramscian maxim 'pessimism of the intellect, optimism of the will' by 'combining a philosophical scepticism about recovering any subaltern agency with a political commitment to making visible the position of the marginalized' (Loomba 1993: 218). Though often accused of nihilism, Spivak is actually making an important intervention in the issue of representing the subaltern. Postcolonial feminist intellectuals tend to guard against constructing the Other as an object of knowledge:

The subaltern cannot speak. There is no virtue in the global laundry lists with 'woman' as a pious item. Representation has not withered away. The female intellectual as intellectual has a circumscribed task which she must not disown with a flourish.

(Spivak 1988: 308)

Spivak problematizes the validity of western representations of Third World women; nonetheless she advocates the continued critical involvement of western feminists in order to make the position of marginal women visible.

One of Spivak's most ethical gestures in this regard is to constantly point out the silencing of women's own narratives. In 'Can the Subaltern Speak?' she writes about the suicide of a young Bengali woman, Bhuvaneswari Bhaduri, in 1926. Bhaduri was secretly part of a pro-independence group that had assigned her the task of performing a political assassination. She was unable to carry out the assignment and committed suicide to 
prove her political loyalty. Unwilling to let society interpret her death as proof of illicit love (for why else would a young woman commit suicide?), she waited until the onset of menstruation to hang herself. Because of this decision, her death fitted neither popular narratives about a women's tragic love affair (she could not be pregnant), nor hegemonic narratives of freedom fighters such as Durga. Thus, it appeared to have no meaning and became insignificant. According to Spivak, Bhuvaneswari's participation in the anticolonial resistance struggle is erased by the supplementary narratives that try to retell her story. The subaltern woman is always forced into this kind of silence.

\section{Towards an 'enlightened' postcolonial subject?}

We can now try to apply Spivak's critique of representation to the specific case of the Bandit Queen. Can we hear her voice without removing the filter of dominant political ideology? According to the critic Bart Moore-Gilbert, the Bandit Queen is one of those clear examples that refute Spivak's dark scenario. In his view, the resistance of subaltern women such as Phoolan Devi is indeed acknowledged and recorded in dominant historiography (Moore-Gilbert 1997: 107). But what has actually been recorded? Phoolan Devi's 'real' story, by any chance? Or perhaps the story that the Indian government wants to tell in order to exploit the fame of a subaltern woman and effectuate a controlled mobilization of outcasts? Or is it a tale that surpasses the personal and becomes 'representative' of the exploitation of women in India, as Kapur's film illustrates?

According to Arundhati Roy, Phoolan Devi the woman has ceased to be important. She has come to stand for many different things according to the interests at stake in representing her. Is this not a case of the collapse between representation (Vertretung) in political terms and re-presentation (Darstellung), as in portraying the subject-construction? Does this imply that Phoolan's agency is erased in the clash between elite nationalist politicians and the western benevolent attempt to speak on her behalf (as if they had direct access to her true self and best interests)? Is Phoolan destined to acquire her political and discursive identity through historically determined systems of political and economic representation?

Phoolan Devi's case is extremely interesting and at the same time problematic when highlighting Spivak's methodological interventions on questions of representation, selfrepresentation and representation of the Other. Phoolan personally dictated part of her memoir to Mala Sen and accepted her version, therefore entrusting others with a level of control over the aesthetic re-presentation (darstellen) of herself. She also agreed to basing the film on the memoir but disagreed with the result of the transposition. ${ }^{4}$ She became a successful politician and therefore could guarantee representation of herself by political proxy (vertreten) and act on behalf of many other outcasts who did not have a clear class consciousness.

Regarding the first case, that of aesthetic re-presentation, we need to take into account that the memoir does not offer us any more unmediated access to the truth of Phoolan Devi's life than the film. Autobiographies, along with memoirs or testimonios, are situated and negotiated texts that are constructed through particular strategies of representation. The production, commodification and distribution of Phoolan Devi's life history through film and autobiography take place within the context of a global, multinational cultural system. There has been a recent rise in consumer demand for the real stories of Third World women in the form of testimonials, autobiographies and documentary films (Trinh 1989). This further complicates the analysis of the politics of representation for

The arena of the colony 101 
the subaltern. Oral testimony and visual spectacle function together in the production of an authentic, realist representation of the Third World subaltern woman. However, in doing so, they show forms of collaboration that simultaneously mark and seek to erase the power relations between the First World and the Third World. ${ }^{5}$

The film Bandit Queen is, like Mala Sen's memoir, a collaborative project between the First and Third Worlds. A British television company funded and produced the film, but the direction and shooting of the film took place in India, with an all-Indian cast. The script was co-written by Mala Sen, Phoolan Devi's biographer, and Shekhar Kapur. The latter is a filmmaker of Indian origin, supposedly better equipped and informed than other western intellectuals to tell 'her story'. However, it is not Kapur's level of awareness in relation to Phoolan's story that matters here, or the cast he selected; there is an additional complication in the audience that he intended to target. This was obviously a western audience, ready to identify with the many stereotypes about the position of women in the Third World, as depicted in western popular culture and even in academic scholarship.

Despite the director's best intentions, Kapur's counter-hegemonic strategies of representation may inadvertently work to re-colonize Phoolan Devi. Devi's opposition to the film signals significant paradoxes in the representation of violence against women. There is always the danger of reproducing a paradigm of victimhood involved in such a representation. The film's emphasis on rape shifts Phoolan Devi from a legendary figure in the Indian context - a woman dacoit, both heroic and notorious - to the status of rape victim. The film's graphic representation of rape as an explanation for Phoolan's transformation into an outlaw transforms rape into the sole motivation for her subsequent actions.

This is in sharp contrast with the autobiography, which deals at length with the complex conception of social justice that motivated Phoolan Devi's numerous raids on various villages. In her vision of justice, resistance was not merely retaliation against her own personal experiences of violence but also against the exploitation of lower-caste villagers by upper-caste landlords. What Devi principally opposed is the 'portrayal' of her subjectivity and economic status as the gendered and lower-caste subject (Darstellung), which collapses into her political representation. She was being spoken for in distorted ways (Vertretung). The consequence was that she had no space left to articulate her own position, which had damaging consequences for her political career at a time (with an upcoming election) when she needed to be portrayed as a strong and independent woman.

A final interesting question is whether Phoolan Devi had become, before her death, an 'enlightened postcolonial subject'. Spivak introduced this term after the attacks of 11 September 2001 on the Twin Towers, in order to discuss the prominent part played by women in the war on terrorism. Take, for example, CNN's representations of empowered US women on aircraft carriers versus the somewhat differently coded representations of the women of Afghanistan. According to Spivak, 'the old topos of intervening for the sake of women continues to be deployed. It is to save Afghan women from terror that we must keep the peace by force of arms' (Spivak 2004: 92). Spivak argues that the liberation of Afghanistan from Taliban rule by the United States did not lead to a corresponding revolution for Afghan women. Rather, Spivak suggests, 'the emancipation of Afghan women needs to come from non-coercive enlightened postcolonial subjects who recognize the particular circumstances and experiences of Afghan women' (Morton 2003: 168). 
It looks as if Spivak seeks to integrate the intransigent and profoundly deconstructive stance she took on the subject of subaltern woman with 'strategic essentialism', as she once called it: the short-term use of essentialism by minority groups to affirm a political identity (e.g. queers, blacks and Muslims). According to Spivak, one 'has to look at where the group - the person, the persons, or the movement - is situated when one makes claims for or against essentialism. A strategy suits a situation; a strategy is not a theory' (Spivak 1993a: 4). It follows that the 'enlightened postcolonial subject' might be better understood as a figuration rather than as a transparent political subject who speaks and acts for herself within specific positions.

The Bandit Queen - in real life and in the stories surrounding this life - has certainly made an intervention, though an ambivalent one, in the debate on the 'enlightened postcolonial subject'. However, the representation of women warriors as 'heroic' and 'fearless', for example in the case of female freedom fighters or suicide bombers, does not necessarily equate to female emancipation. When women are shown to carry bombs during the Algerian revolution (analyzed by Fanon and filmed by Pontecorvo), their active role in resistance movements is made visible. The same is true for Palestinian women who prepare or commit suicide bombings for Hamas; or for women active in other political movements such as the Tamil Tigers in Sri Lanka (see The Terrorist, a film by Santosh Sivan from 1998) or the Kashmir liberation movement (see the film Dil Se by Mani Ratman from 1998). Yet, the representations of these women as heroic freedom fighters are often subordinated to a masculine and nationalist historiography, in a way not dissimilar to the case of Bhuvaneswari Bhaduri (see Ponzanesi 2014a and 2014b). Women in these texts are interpellated in a male revolutionary rhetoric but they hardly come to share in the success of political governance once their revolution overturns colonialism or the oppressive regime. This is corroborated by many stories of nationalistic movements such as the tegalit (female combatants of the Eritrean Popular Liberation Front) who, after the victory ending Ethiopian occupation in 1991, receded into the background of patriarchal society. Or the Women's League, the organization of black South African women founded in 1943, who supported the ANC struggle against apartheid but who did not gain direct visibility in return for their contribution to the struggle. ${ }^{6}$ As is argued by McClintock, women are often the symbols of nation building - think of the figure of Marianne in France or the Volksmoeder in the case of the Afrikaner myth of the South African nation - but never the subject of this process (McClintock 1997).

On the other hand, female suicide bombers certainly are not Orecorded in the western media as 'enlightened postcolonial subjects' but as terrorists who resurrect the figure of a monster, a sexually, racially and psychologically deviant subject. In their article 'Monster, Terrorist, Fag', Puar and Rai describe how, after the attack on the Twin Towers, posters appeared in midtown Manhattan showing a turbaned caricature of Bin Laden being anally penetrated by the Empire State Building. The caption beneath read: 'The Empire Strikes Back'. Other forms of gender-based black humour describe the appropriate measure to punish Bin Laden: he undergoes a sex operation and must live as a woman in Afghanistan. These portrayals of American retaliation that promise to emasculate Bin Laden and turn him into a fag entail deeply racist, sexist and homophobic suggestions. According to Puar and Rai, the US nation state has experienced both castration and penetration of its capitalist masculinity and offers up a narrative of emasculation as the appropriate punishment for Bin Laden, brown-skinned folks, and men in turbans in general (Puar and Rai 2002: 126). 
Puar and Rai maintain that the monsters that haunt the stories of current counter-terrorism have emerged from the pre-modern monsters of western civilization, from those who in the eighteenth and nineteenth centuries were classified, racialized and sexualized as the persona non grata, the vagrant, the Gypsy, the savage, the Hottentot Venus, or the sexually depraved Oriental. The intent of terrorism studies, they argue, is to reduce complex social, historical and political dynamics to western models rooted in the dynamics of the bourgeois heterosexual family. The questions of political economy and the problem of cultural translation are kept out of such studies, as are the attempts to master fear, anxiety and uncertainty about a form of political dissent. Instead, these studies resort to the banality of a taxonomy of the terrorist-monster.

\section{Conclusion}

Since 11 September 2001 and the ISIS attacks in Paris (2015) and Brussels (2016), there has been a backlash in the construction of the Other. The uncritical contiguity between pre-modern and postmodern representations is not only left unchallenged but is, in fact, being reinforced. The new right-wing terminology proposes again, and without any critical self-reflection, the dual narrative of enlightened modernity and secularism versus tradition and fundamentalism. Religion and fundamentalism are seen as new categories through which the division between the enlightened West and backward Rest is achieved. Women in the Third World are often seen as victims of religious indoctrination and as suffering from false consciousness (see the recent upheavals with ISIS and the participation of women in religious movements, Rajan 2015). This leads to the endless construction of the 'suspicious' Other as the foundation for defining the Self. The collapse between political and aesthetic representation is thus magnified, as the Other does not have access to his/her own awareness - white men are saving brown men/women from brown men; that is, from fundamentalists, fanatics, terrorists - yet needs to be represented politically. He/she cannot dispose of a shared social and political group consciousness (they cannot represent themselves, they must be represented) and so the Other is susceptible to the ruling ideas of unenlightened, undemocratic and tyrannical leaders. These dictators must therefore be overthrown in the name of civilization, articulated as a western project of modernity. The collapse of representation in the two senses of Vertretung (domination in geopolitics) and Darstellung (implying exploitation within global capitalism), damages the position of women more than ever. In the international division of labour, women who are subjected to this double regime of erasure become extremely vulnerable.

Women warriors, such as the Bandit Queen and suicide bombers, are inscribed in a complex regime of representation that not only appropriates them at the level of subject-construction (both for nationalist and transnational projects) but also exploits them within the global context of multinational cultural production (they are marketed as iconic figures of oppression or rebellion). The enduring lesson of feminist postcolonial critique is to stay alert to this reproposed collapse, which is colonialist in nature but is subtly and deceptively disguised in general global dynamics. Sadly, the new global order once more underscores Spivak's epistemological position that the 'subaltern cannot speak'. The political commitment of postcolonial critique in making the position of the marginalized visible is thus made all the more important.

This requires a lot of homework. Postcolonial theory's major intervention in cultural critique is to account for the political in the aesthetic system of representation at a global 
level, something which has been neglected by other fields of studies so far. This can only be achieved the hard way: through deconstructive analysis as illustrated in this chapter, in order to understand the local articulations of power and resistance and to hear the gendered subaltern voice without resorting to pre-set paradigms of emancipation and progress and without ventriloquizing (speaking for) the Other.

\section{Notes}

1 It is hard to give Phoolan Devi's date of birth with any accuracy (1957? 1963? 1968?); the most likely date is 1963. What we know for sure is her date of death (2001).

2 For a reading of Devi as a popular icon and the media frictions see Ghosh 2011. Other interesting articles among the vast literature are Fernandes 1999 and Murty 2009.

3 The category of the subaltern is something Spivak borrows from the Italian political thinker, Antonio Gramsci (1891-1937). He used the term subaltern to refer to 'unorganized groups' of rural peasants in Southern Italy, who had no social and political consciousness as a group and were therefore susceptible to the ruling ideas, culture and leadership of the state. In postcolonial terms, and in Spivak's inflection, the subaltern is everyone who has limited or no access to the field of cultural imperialism and which constitutes a space of difference.

4 For a discussion of the film adaptation and the postcolonial implications see Ponzanesi 2012.

5 After the controversy with Channel 4, Phoolan Devi sold her story many more times. It is clear that it is hard to evaluate the extent to which Devi manipulated the western media as she has offered them different versions of her story. The same goes for the way in which her story keeps being retold in the same format - meaning the emphasis on heroism and victimhood — for the sake of western society's voyeurism and paternalism.

6 Viz. the novel David's Story (2001) by the South African writer Zoë Wicomb. Dulcie is a female member of the ANC guerrilla unit and sacrifices both her voice and her sexuality for the ANC. She is never fully articulated in the novel, but her importance in David's life and to the movement is invaluable. Dulcie's elusiveness is a statement of the elusiveness of the double victim of colonialism and patriarchy. The novel confirms Spivak's argument that at times representation wholly inadequately articulates the non-dominant voice, such as that of the women involved in the movement.

\section{Questions}

1. Try and form an idea of the part played by white women in the colonies, by studying chapters 5 and 6 . Describe your impressions and emphasize the way in which patriarchal relations and racist superiority are related to each other in the colonial setting.

2. Search the internet for examples of the portrayal of colonized women in western media (literature, paintings, photography, postcards, travel accounts, diaries, films, songs, letters and documents and papers). Regarding Spivak, do you think it is possible to retrieve the position and voice of colonized women?

3. What are the alternative images construed by postcolonial women in order to resist dominant representations? Give some examples of the differences between postcolonial feminism and feminism in general.

4. To what extent do you believe that colonial dividing lines still determine the world order, for instance in the discourse on the 'clash of civilizations'? Would you say that colonialism is at the heart of globalization? What then are the differences between these two phenomena? 